\title{
Distribution and diversity of Papilionidae and Pieridae (Lepidoptera: Papilionoidea) in Loxicha Region, Oaxaca, Mexico
}

\author{
Armando Luis-Martínez¹, Alejandra Sánchez García², Omar Ávalos-Hernández * , \\ José Luis Salinas-Gutiérrez ${ }^{3}$, Marysol Trujano-Ortega ${ }^{1}$, Arturo Arellano-Covarrubias ${ }^{1}$ \\ \& Jorge Llorente-Bousquets ${ }^{1}$
}

1. Museo de Zoología (Entomología), Departamento de Biología Evolutiva, Facultad de Ciencias, Universidad Nacional Autónoma de México, Av. Universidad 3000, Circuito Exterior S/N, C.P. 04510, Ciudad de México, Mexico; alm@ciencias.unam.mx, omaravalosh@ciencias.unam.mx,marysol_trujano@yahoo.com.mx, arellano.covarrubias@gmail.com, enantia@prodigy.net.mx

2. Departamento de Ingeniería Industrial, Tecnológico Nacional de México campus Tecnológico de Estudios Superiores de Chimalhuacán, Calle Primavera S/N, Colonia Santa María Nativitas, C.P. 53330, Chimalhuacán, Estado de México, Mexico; alexa.ciencias@gmail.com

3. Colegio de Postgraduados, Campus Montecillo, Km 36.5, Carretera México-Texcoco, C.P. 56230, Texcoco, Estado de México, Mexico; salinasgtez@colpos.mx

* Correspondence

Received 06-VI-2019. Corrected 01-IX-2019. Accepted 21-I-2020.

\begin{abstract}
Introduction: A reliable list of species and the analysis of diversity patterns of hyperdiverse taxa, like butterflies, are fundamental for monitoring and managing biological resources. Oaxaca is one of the most diverse states in Mexico for many groups including Lepidoptera and most of its diversity is unknown. Objective: to estimate and describe the species richness and diversity of Papilionidae and Pieridae along an altitudinal gradient and five vegetation types in the Loxicha Region, Oaxaca, Sierra Madre del Sur. Methods: Sampling effort comprised 222 collecting days during a period of seven years. We estimated the alpha diversity for 17 sites within an elevational gradient from 80 to $2850 \mathrm{~m}$, with five vegetation types: tropical deciduous forest (TDF), tropical sub-deciduous forest (TSDF), cloud forest (low and middle levels) (CF), oak-pine and cloud forest (high level) (OPCF) and oak-pine forest (OPF). Results: We obtained a list of 69 species (27 Papilionidae and 42 Pieridae), of 34 genera and five subfamilies, from literature records and fieldwork. These species are $60 \%$ of the Pieridae and $48 \%$ of the Papilionidae recorded for the state. The Loxicha Region has $36 \%$ of the Pieridae and $30 \%$ of the Papilionidae of Mexico. Both families present different species richness patterns by vegetation type. Papilionidae is richer in the TDF with 23 estimated species and most of the species of this family ( $84 \%$ ) occur below $500 \mathrm{~m}$. Meanwhile, species richness of Pieridae has non-significant differences among vegetations types, except for OPF which has fewer species than the other types. The elevational gradient was divided into three levels $(0-750,750-1800,1800-2850 \mathrm{~m})$ showing a reduction of species richness and diversity for both families at higher altitudes. Conclusions: Papilionidae species are more restricted to a vegetation type or elevational level than Pieridae species. Likely reasons are higher vagility (including migrations) and wider ecological tolerance of most Pieridae.
\end{abstract}

Key words: butterflies, abundance, species richness estimation, altitudinal distribution, cloud forest.

Luis-Martínez, A., Sánchez García, A., Ávalos-Hernández, O., Salinas-Gutiérrez, J.L., TrujanoOrtega, M., Arellano-Covarrubias, A., \& Llorente-Bousquets, J. (2020). Distribution and diversity of Papilionidae and Pieridae (Lepidoptera: Papilionoidea) in Loxicha Region, Oaxaca, Mexico. Revista de Biología Tropical, 68(1), 139-155. 
The main product of faunistic studies is the list of species of a specific geographic area. These lists allow the recognition of exclusive and characteristic species of each area, vegetation type or altitudinal level, including bioindicator species (Bonebrake, Ponisio, Boggs, \& Ehrlich, 2010; González-Valdivia et al., 2011; Pozo, Luis-Martínez, Salas-Suárez, Trujano-Ortega, \& Llorente-Bousquets, 2015). Estimation of the species richness is fundamental in faunistic research because it gives confidence for the completeness of the list. A complete list of species at a local scale allows the recognition of diversity patterns at greater biogeographic scales (Beccaloni \& Gaston, 1995; Martín-Piera, 2000; Monteagudo-Sabaté, Luis-Martínez, Vargas-Fernández, \& LlorenteBousquets, 2001; Magurran, 2006). Therefore the analysis of the fauna of an area can be used to know the geographic distribution of the species; but also, the comparison of the fauna between related areas can be useful in the interpretation of ecological biogeography patterns like fauna exchange between areas or latitudinal patterns of diversity (Holt, 1993; Arita \& Rodríguez, 2001; Rodríguez \& Arita, 2005).

Worldwide, ecosystems are being transformed at a high rate, making inventories of local diversity of unexplored areas a priority. This allows recognizing areas with high endemism or diversity. With this information, we can focus the conservation efforts and resource use policies, including the proposal of protected conservation areas. In the conservation context, Papilionoidea is known as a good bioindicator because of their diversity, enough knowledge about their natural history, easy sampling and identification, compared with other insects, and great functional importance in the ecosystem, being herbivores and pollinators (Sparrow, Sisk, Ehrlich, \& Murphy, 1994; Kocher \& Williams, 2000; Thomas, 2005; Pozo et al., 2015). Particularly, Papilionidae and Pieridae have been used in Mexico as models for describing altitudinal patterns of diversity (LlorenteBousquets, Trujano-Ortega, Luis-Martínez, Castro, \& Vargas-Fernández, 2006; OñateOcaña, Trujano-Ortega, Llorente-Bousquets,
Luis-Martínez, \& Vargas-Fernández, 2006; Monteagudo-Sabaté \& Luis-Martínez, 2013).

Oaxaca is one of the most diverse states in Mexico (García-Mendoza, Ordóñez, \& Briones-Salas, 2004). This is because five biogeographic provinces converge in the state; with Sierra Madre del Sur, Costa del Pacífico, and Golfo de México provinces covering most of the state area (Morrone, Espinosa-Organista, Llorente-Bousquets, 2002; Morrone 2005). The Loxicha Region is located in the South of Oaxaca, as part of the Sierra Madre del Sur province. The lepidopterological history of the Loxicha Region has two periods, first during the 60 's, E. Welling collected in the Region and that material was acquired by the Allyn Museum from which new species were described (Paramacera xicaque rubrosuffusa Miller, 1972, Cyllopsis jacquelineae Miller, 1974, Altinote stratonice oaxaca (Miller \& Miller, 1979) and Chlosyne gaudialis wellingi Miller \& Rotger, 1979). Later, in the late 70's and early 80 's the De la Maza family also took interest in the region and described new taxa as well Fountainea nobilis rayoensis (Maza \& Díaz, 1978) and Callicore texa loxicha Maza \& Maza, 1983). However, this is the first study with systematic sampling made in the Region.

The aim of this work is to estimate and describe the species richness and diversity of Papilionidae and Pieridae along an altitudinal gradient from 80 to $2850 \mathrm{~m}$ and for each vegetation type present in the Loxicha Region. This study is part of a wider project whose objective is to describe the geographic distribution patterns of Papilionoidea (sensu Kristensen, 1976) in Oaxaca. The research is based on exhaustive faunistic inventories; with sampling focused on high diversity areas, in order to know the local distribution and phenology of the species, but particularly the endemic taxa of Mexico and Oaxaca.

\section{MATERIALS AND METHODS}

Sampling sites: Systematic sampling of the Papilionoidea of Oaxaca began in 2005 (Luis-Martínez et al., 2016). In the Loxicha 
Region, sampling effort consisted of 222 collecting days along seven years $(2005,2007$, 2008, 2011-2014) in 17 sites of seven municipalities, all within the Sierra Madre del Sur mountain range in the Pacific slope. Systematic sampling of 10 or more days along the year, with at least five collectors each day, were made in 13 sites. In order to recognize diversity patterns, sites were grouped in three altitudinal levels: 0-750, 750-1800, 1800-2850 m. These ranges were selected because they represent the natural upper and lower limits of the tropical, cloud and oak-pine forests in Mexico (Llorente-Bousquets, 1984; Rzedowski, 2006). Sites also were grouped in five vegetation types: tropical deciduous forest (TDF), tropical sub-deciduous forest (TSDF), cloud forest (low and middle levels) (CF), oak-pine and cloud forest (high level) (OPCF) and oak-pine forest (OPF) (Table 1, Fig. 1). The classification of the vegetation follows Rzedowski (2006), which has been the main classification used in Mexico because it considers the historical and ecological aspects of the vegetation types present in the country. The sites Puente Arroyo "El Guajolote" and San José del Pacífico $1 \mathrm{~km} \mathrm{~S}$, in the altitudinal range of 2000-2400 m, have particular vegetation types. San José del Pacífico presents the high-mountain CF and Puente Arroyo "El Guajolote" marks the upper limit of the CF characteristic of the mid-level, as described by Llorente-Bousquets (1984). Both sites present mainly OPF in the mountainsides, but in the rifts, where most of the species were collected, the CF is dominant. Therefore, the vegetation type on these sites was defined as a mix between low-altitude oak-pine forest and high-altitude cloud forest (OPCF) and is treated as an independent type, distinct from the highaltitude oak-pine forest (OPF) and the cloud forest of the low and middle levels (CF).

Taxonomic determination: Species identification was made by comparison with the specimens in the Lepidoptera Collection of the Zoology Museum, Facultad de Ciencias,

TABLE 1

Sampling sites

\begin{tabular}{|c|c|c|c|c|c|c|}
\hline Site & $\mathrm{SE}^{1}$ & $\mathrm{~N}^{2}$ & Altitude ${ }^{3}$ & Lat $\mathrm{N}$ & Long W & $\mathrm{Veg}^{4}$ \\
\hline a. Parque Nacional Huatulco, río Cacaluta & 17 & 844 & $80-100$ & $15^{\circ} 47^{\prime} 07^{\prime \prime}$ & $96^{\circ} 10^{\prime} 34^{\prime \prime}$ & TDF \\
\hline b. Parque Nacional Huatulco & 22 & 502 & 100 & $15^{\circ} 45^{\prime} 20^{\prime \prime}$ & $96^{\circ} 09^{\prime} 19^{\prime \prime}$ & TDF \\
\hline c. El Azulillo & 43 & 1829 & $380-500$ & $15^{\circ} 53^{\prime} 25^{\prime \prime}$ & $96^{\circ} 29^{\prime} 27^{\prime \prime}$ & TSDF \\
\hline d. Rancho Hagia Sofía & 39 & 1553 & 410 & $15^{\circ} 52^{\prime} 01^{\prime \prime}$ & $96^{\circ} 21^{\prime} 55^{\prime \prime}$ & TSDF \\
\hline e. Río Molinos* & 2 & 29 & $530-700$ & $15^{\circ} 56^{\prime} 10^{\prime \prime}$ & $96^{\circ} 30^{\prime} 41^{\prime \prime}$ & $\mathrm{CF}$ \\
\hline f. Magdalena, El Lirio & 11 & 349 & $750-900$ & $15^{\circ} 55^{\prime} 11^{\prime \prime}$ & $96^{\circ} 23^{\prime} 34^{\prime \prime}$ & $\mathrm{CF}$ \\
\hline g. Copalita-río Copalita & 27 & 271 & $850-1200$ & $15^{\circ} 56^{\prime} 48^{\prime \prime}$ & $96^{\circ} 20^{\prime} 23^{\prime \prime}$ & $\mathrm{CF}$ \\
\hline h. Pluma Hidalgo, 4 km NW "La Curva" & 24 & 637 & $1100-1200$ & $15^{\circ} 56^{\prime} 23^{\prime \prime}$ & $96^{\circ} 25^{\prime} 59^{\prime \prime}$ & $\mathrm{CF}$ \\
\hline i. Finca Aurora-Finca San Isidro & 12 & 285 & $1100-1250$ & $15^{\circ} 56^{\prime} 30^{\prime \prime}$ & $96^{\circ} 24^{\prime} 13^{\prime \prime}$ & $\mathrm{CF}$ \\
\hline j. Portillo del Rayo-Finca El Encanto & 10 & 444 & $1200-1530$ & $15^{\circ} 58^{\prime} 38^{\prime \prime}$ & $96^{\circ} 31^{\prime} 11^{\prime \prime}$ & $\mathrm{CF}$ \\
\hline k. La Soledad-Buenavista & 21 & 569 & $1470-1550$ & $15^{\circ} 58^{\prime} 18^{\prime \prime}$ & $96^{\circ} 31^{\prime} 54^{\prime \prime}$ & $\mathrm{CF}$ \\
\hline 1. La Pasionaria & 10 & 229 & $1500-1650$ & $15^{\circ} 66^{\prime} 09^{\prime \prime}$ & $96^{\circ} 25^{\prime} 08^{\prime \prime}$ & $\mathrm{CF}$ \\
\hline m. Puente Arroyo "El Guajolote" & 10 & 184 & $2020-2150$ & $16^{\circ} 03^{\prime} 28^{\prime \prime}$ & $96^{\circ} 30^{\prime} 18^{\prime \prime}$ & OPCF \\
\hline n. San José del Pacífico, $1 \mathrm{~km} \mathrm{~S}$ & 27 & 950 & $2280-2400$ & $16^{\circ} 09^{\prime} 28^{\prime \prime}$ & $96^{\circ} 29^{\prime} 21^{\prime \prime}$ & OPCF \\
\hline o. Manzanal-Doncella* & 4 & 27 & $2700-2800$ & $16^{\circ} 07^{\prime} 47^{\prime \prime}$ & $96^{\circ} 30^{\prime} 12^{\prime \prime}$ & OPF \\
\hline p. Camino a San Agustín Loxicha* & 3 & 30 & $2700-2800$ & $16^{\circ} 07^{\prime} 41^{\prime \prime}$ & $96^{\circ} 29^{\prime} 54^{\prime \prime}$ & OPF \\
\hline q. Nevería-La Ciénega* & 1 & 1 & $2820-2850$ & $16^{\circ} 12^{\prime} 01{ }^{\prime \prime}$ & $96^{\circ} 20^{\prime} 56^{\prime \prime}$ & OPF \\
\hline
\end{tabular}

* sites with isolated sampling, non-systematic.

${ }^{1}$ sampling effort, days, ${ }^{2}$ abundance, specimens collected, ${ }^{3}$ elevation, ${ }^{4}$ vegetation type, TDF $=$ tropical deciduous forest, $\mathrm{TSDF}=$ tropical sub-deciduous forest, $\mathrm{CF}=$ cloud forest (low and middle levels), OPCF $=$ oak-pine and cloud forest (high level), OPF = oak-pine forest. 
UNAM (MZFC). The taxonomic arrangement follows Llorente-Bousquets, Luis-Martínez, and Vargas-Fernández (2006) and VargasFernández, Llorente-Bousquets, and Luis-Martínez (2016). All specimens were deposited in the Lepidoptera Collection (MZFC), registered at the Secretaría de Medio Ambiente, Recursos Naturales y Pesca (SEMARNAP) (DFE. IN.071.0798). Specimens were collected under the scientific collect permit FAUT-0148 issued by the Secretaría de Medio Ambiente y Recursos Naturales (SEMARNAT). Collecting data were captured into the database MARIPOSA (Luis-Martínez, Llorente-Bousquets, \& VargasFernández, 2005).

Taxonomic inventory: The list of species was elaborated with the collected material, a review of previously published inventories for the area and material deposited in national and international collections (1940-2000). Data were obtained from the MARIPOSA database (Luis-Martínez et al., 2005).

Comparison of the diversity of the Loxicha Region with other areas: Species richness of Loxicha were compared with the richness of two areas in Oaxaca and two of states within the Pacific slope: Sierra de Juárez, Oaxaca (Luis-Martínez, Vargas-Fernández, \& LlorenteBousquets, 1991), Sierra Mazateca, Oaxaca (Álvarez-García, Ibarra, \& Escalante, 2016), Sierra de Átoyac de Álvarez, Guerrero (Vargas-Fernández, Llorente-Bousquets, \& LuisMartínez, 1991), and Sierra de Manantlán, Jalisco-Colima (Vargas-Fernández, LlorenteBousquets, \& Luis-Martínez, 1999). Sampling sites were ranked according to its species richness within Oaxaca (Luis-Martínez et al., 2016) and also compared with the diversity of the country (Llorente-Bousquets et al., 2014).

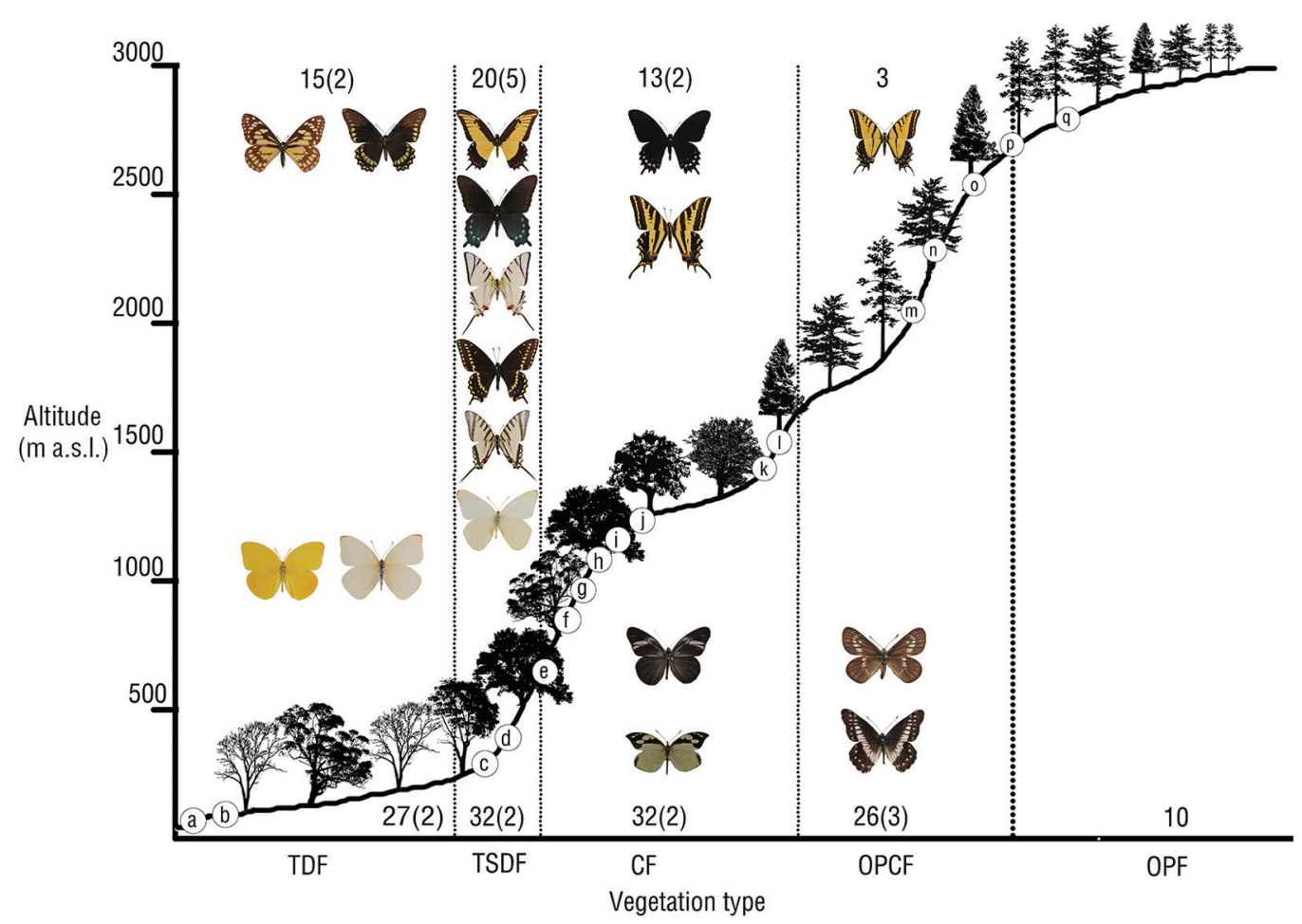

Fig. 1. Altitudinal distribution and by vegetation type of species richness and exclusive species (bracket number) of Papilionidae (top) and Pieridae (bottom) in the Loxicha Region. Sites identification letters correspond with Table 1. 
Species richness was estimated for each site and regions with non-parametric estimators Chao1, ACE, Chao2, and ICE (Colwell \& Coddington, 1994; Chazdon, Colwell, Deslow, \& Guariguata, 1998); using EstimateS 9 (Colwell, 2016). Species richness of both families was estimated with the non-parametric estimator Chao1 (Colwell \& Coddington, 1994) using SPADE (Chao \& Shen, 2010) for each vegetation type (Table 1, Fig. 1) and for the three altitudinal levels $(0-750,750-1$ 800, 1 $800-2850 \mathrm{~m})$. For each estimation, a confidence interval (CI) $(95 \%)$ was calculated by bootstrap using the standard error. Significant differences were evaluated by the CI overlap between estimations. True diversity or effective number of species (Jost, 2006) was estimated as the exponential of the ShannonWiener $\left(H^{\prime}\right)$ diversity index for each altitudinal level. Estimation was made with the Chao and Shen (2003) and Chao, Chazdon, Colwell, and Tsung-Jen (2005) method using SPADE (Chao \& Shen, 2010). Effective number of species is the diversity expressed on a linear scale, contrary to Shannon-Wiener $\left(H^{\prime}\right)$ index which is on a logarithmic scale, therefore, the effective number of species can be compared directly between altitudinal levels, simplifying it interpretation (Jost, 2006).

\section{RESULTS}

List of species: The literature review (1950-2000) and database MARIPOSA query (Luis-Martínez et al., 2005) resulted in a list of 57 species (22 Papilionidae and 35 Pieridae) of seven sites in the Loxicha Region (400$2500 \mathrm{~m}$ ). None of the sites had enough and systematic sampling effort or analysis of the distribution of the species. We captured 8733 specimens (Table 2) and added 12 new records to the species list; five Papilionidae: Baronia $b$. brevicornis, Battus eracon, Papilio polyxenes asterius, Pterourus m. multicaudata, Pterourus pilumnus; and seven Pieridae: Pyrisitia lisa centralis, Abaeis nicippe, Nathalis iole iole, Anteos clorinde, Prestonia clarki, Catasticta

TABLE 2

Species richness and abundance by site of Papilionidae and Pieridae of the Loxicha Region

\begin{tabular}{lccccc}
\multicolumn{1}{c}{ Site } & \multicolumn{2}{c}{ Papilionidae } & \multicolumn{2}{c}{ Pieridae } & \multicolumn{2}{c}{ Total } \\
& Species & N & Species & N & Species \\
a. Parque Nacional Huatulco, río Cacaluta & 12 & 258 & 24 & 586 & 36 \\
b. Parque Nacional Huatulco & 9 & 58 & 23 & 444 & 32 \\
c. El Azulillo & 15 & 140 & 28 & 1689 & 43 \\
d. Rancho Hagia Sofía & 17 & 190 & 30 & 1363 & 47 \\
e. Río Molinos & 0 & 0 & 9 & 29 & 9 \\
f. Magdalena, El Lirio & 4 & 12 & 20 & 337 & 24 \\
g. Copalita-río Copalita & 6 & 14 & 16 & 257 & 22 \\
h. Pluma Hidalgo, 4 km NW "La Curva" & 2 & 2 & 26 & 621 & 28 \\
i. Finca Aurora-Finca San Isidro & 3 & 3 & 17 & 275 & 20 \\
j. Portillo del Rayo-Finca El Encanto & 5 & 12 & 22 & 432 & 27 \\
k. La Soledad-Buenavista & 2 & 21 & 19 & 548 & 21 \\
1. La Pasionaria & 4 & 18 & 16 & 211 & 20 \\
m. Puente Arroyo "El Guajolote" & 3 & 20 & 17 & 164 & 20 \\
n. San José del Pacífico, 1 km S & 3 & 71 & 26 & 879 & 29 \\
o. Manzanal-Doncella & 0 & 0 & 6 & 27 & 6 \\
p. Camino a San Agustín Loxicha & 0 & 0 & 8 & 30 & 1 \\
q. Nevería-La Ciénega & 0 & 0 & 1 & 42 & 7914 \\
Total & 27 & 819 & & & 69 \\
\hline
\end{tabular}

$\mathrm{N}=$ Specimens 
n. nimbice, and Catasticta oaxaca. Literature and collection data are mainly from the 400 to $1400 \mathrm{~m}$ altitude range. New records are from the $80-600 \mathrm{~m}$ range, from the TDF, and also from above the $2000 \mathrm{~m}$, from the OPCF. With these records, the list increases to 69 species (27 Papilionidae and 42 Pieridae). This richness represents $68 \%$ of the Papilionidae and $69 \%$ of the Pieridae in Oaxaca (Luis-Martínez et al., 2016); with $30 \%$ and $8 \%$ endemic species, respectively (Luis-Martínez et al., 1991). Also, this Region has $56 \%$ of the diversity of Mexico of each family (Llorente-Bousquets et al., 2014). Ganyra phaloe tiburtia (Pieridae) is reported for this area but was not collected during this study.

List of species of Papilionidae and Pieridae of the Loxicha, Region, Sierra Madre del Sur, Oaxaca. (Bold, endemic species of Mexico; underlined, new records for Loxicha Region; \#; species not collected).

\section{PAPILIONIDAE}

\section{Papilioninae}

1. Baronia brevicornis brevicornis Salvin, 1893

2. Battus eracon (Godman \& Salvin, 1897)

3. Battus philenor philenor (Linnaeus, 1771)

4. Battus polydamas polydamas (Linnaeus, 1758)

5. Heraclides anchisiades idaeus (Fabricius, 1793)

6. Heraclides androgeus reyesorum Vargas, Llorente \& Luis, 2012

7. Heraclides astyalus bajaensis (J.W. Brown \& Faulkner, 1992)

8. Heraclides erostratus vazquezae (Beutelspacher, 1986)

9. Heraclides ornythion ssp. $\mathrm{n}$

10. Heraclides rogeri pharnaces (Doubleday, 1846)

11. Heraclides rumiko Shiraiwa \& Grishin, 2014

12. Heraclides thoas autocles (Rothschild \& Jordan, 1906)

13. Mimoides aconophos (Gray, [1853])
14. Mimoides ilus occiduus (Vázquez, 1957)

15. Mimoides phaon phaon (Boisduval, 1836)

16. Papilio polyxenes asterius Stoll, 1782

17. Parides erithalion trichopus (Rothschild \& Jordan, 1906)

18. Parides montezuma (Westwood, 1842)

19. Parides photinus (Doubleday, 1844)

20. Protesilaus macrosilaus penthesilaus (C. Felder \& R. Felder, 1865)

21. Protographium agesilaus fortis (Rothschild \& Jordan, 1906)

22. Protographium epidaus fenochionis (Salvin \& Godman, 1868)

23. Protographium philolaus philolaus (Boisduval, 1836)

24. Pterourus multicaudata multicaudata (W.F. Kirby, 1884)

25. Pterourus pilumnus (Boisduval, 1836)

26. Pyrrhosticta baroni (Rothschild \& Jordan, 1906)

27. Pyrrhosticta menatius morelius (Rothschild \& Jordan, 1906)

\section{PIERIDAE \\ Dismorphinae}

28. Dismorphia amphione isolda Llorente, 1984

29. Enantia mazai diazi Llorente, 1984

30. Lieinix nemesis nayaritensis Llorente, 1984

\section{Coliadinae}

31. Abaeis nicippe (Cramer, 1779)

32. Anteos clorinde (Godart, [1824])

33. Anteos maerula (Fabricius, 1775)

34. Aphrissa statira statira (Cramer, 1777)

35. Eurema daira (Wallengren, 1860)

36. Eurema albula celata (R. Felder, 1869)

37. Eurema arbela boisduvaliana (C. Felder \& R. Felder, 1865)

38. Eurema mexicana mexicana (Boisduval, 1836)

39. Eurema salome jamapa (Reakirt, 1866)

40. Kricogonia lyside (Godart, 1819)

41. Nathalis iole iole Boisduval, 1836 
42. Phoebis agarithe agarithe (Boisduval, 1836)

43. Phoebis argante ssp. $\mathrm{n}$.

44. Phoebis neocypris virgo (Butler, 1870)

45. Phoebis philea philea (Linnaeus, 1763)

46. Phoebis sennae marcellina (Cramer, 1777)

47. Prestonia clarki Schaus, 1920

48. Pyrisitia dina westwoodi (Boisduval, 1836)

49. Pyrisitia lisa centralis (Herrich-Schäfferm 1865)

50. Pyrisitia nise nelphe (R. Felder, 1869)

51. Pyrisitia proterpia (Fabricius, 1775)

52. Rhabdodryas trite ssp. $\mathrm{n}$.

53. Zerene cesonia cesonia (Stoll, 1790)

\section{Pierinae}

54. Ascia monuste monuste (Linnaeus, 1764)

55. Catasticta flisa flisa (Herrich-Schäffer, [1858])

56. Catasticta nimbice nimbice (Boisduval, 1836)

57. Catasticta oaxaca Beutelspacher, 1984

58. Catasticta teutila ssp. nov.

59. Eucheira socialis socialis Westwood, 1834

60. Ganyra josephina josepha (Salvin \& Godman, 1868)

61. Ganyra phaloe tiburtia (Fruhstorfer, 1907) \#

62. Glutophrissa drusilla tenuis (Lamas, 1981)

63. Hesperocharis costaricensis pasion (Reakirt, [1867])

64. Hesperocharis graphites avivolans (Butler, 1865)

65. Itaballia demophile centralis Joicey \& Talbot, 1928

66. Leptophobia aripa elodia (Boisduval, 1836)

67. Melete lycimnia isandra (Boisduval, 1836)

68. Pereute charops sphocra Draudt, 1931

69. Pieriballia viardi viardi (Boisduval, 1836)

Eight of the nine sampled sites are among the 20 most diverse sites of Oaxaca for Papilionidae and Pieridae. The sites El Azulillo and Rancho Hagia Sofía are among the 50 most diverse for these families in Mexico (LlorenteBousquets, Oñate-Ocaña, Luis-Martínez, \& Vargas-Fernández, 1997). For the Pacific slope, Rancho Hagia Sofía is the third most diverse site with 17 species of Papilionidae, just below Mapastepec in Chiapas (19 species) and Agua Dulce in Colima (18 species); and with 30 species of Pieridae, same as Calera in Jalisco, both below San Jerónimo, Tacaná in Chiapas with 33 species.

Alpha diversity: During field-work 68 species were collected, estimations range from 68 to 78 species and list completeness range from 87 to $100 \%$ according to these estimations. (ICE: Estimated species, Est. sp. $=71$, completeness, Comp. $=96 \%$; Chao2: Est. Sp. $=70$, Comp. $=97 \%$; ACE: Est. sp. $=68$, Comp. $=100 \%$; Chao1: Est. Sp. $=73$, Comp. $=93 \%$ ). ACE estimator shows that $100 \%$ of the species of the Loxicha Region were recorded. This is unlikely given the high number of singletons in the samples. All estimators behave correctly reaching a stable value in the first samples.

Diversity of the Loxicha and other regions of Mexico: Species richness comprises 27 species of Papilionidae (50\% endemic of Mexico) and 42 species of Pieridae (19 $\%$ endemic of Mexico). This richness places Loxicha as the most diverse altitudinal gradient of the Pacific slope and the second most diverse region of the state, just below Sierra de Juárez (Table 3) (Luis-Martínez et al., 1991; Vargas-Fernández et al., 1991, 1999; LlorenteBousquets et al., 1997; Álvarez-García et al., 2016). Four of the compared regions have enough sampling effort and lists of species have a completeness level above $88 \%$, according to the non-parametric estimations; for Sierra Mazateca (Álvarez-García et al., 2016) sampling effort data are not available, therefore estimations were not made.

Phenology: Temporal distribution of the species richness and abundance of these families is influenced by the seasons of the year (Fig. 2). Richness and abundance are higher 
TABLE 3

Species richness of five altitudinal gradients of Mexico

\begin{tabular}{|c|c|c|c|c|c|c|c|}
\hline \multirow{2}{*}{ Altitudinal gradient / Species richness } & \multicolumn{3}{|c|}{ Observed } & \multicolumn{4}{|c|}{ Estimated } \\
\hline & Papilionidae & Pieridae & Total & $\mathrm{ChaO}_{2}$ & $\% 1$ & ICE & $\% 1$ \\
\hline \multicolumn{8}{|l|}{ Pacific slope } \\
\hline Sierra Manantlán, Jalisco-Colima & 24 & 37 & 61 & 63 & 97 & 65 & 94 \\
\hline Sierra Atoyac de Álvarez, Guerrero & 20 & 37 & 57 & 62 & 92 & 65 & 88 \\
\hline Región Loxicha, Oaxaca & 27 & 42 & 69 & 70 & 97 & 71 & 96 \\
\hline \multicolumn{8}{|l|}{ Atlantic slope } \\
\hline Sierra de Juárez, Oaxaca & 37 & 50 & 87 & 90 & 97 & 90 & 97 \\
\hline Sierra Mazateca, Oaxaca & 18 & 40 & 58 & & & & \\
\hline
\end{tabular}

${ }^{1}$ Percentage of completeness of the species list.

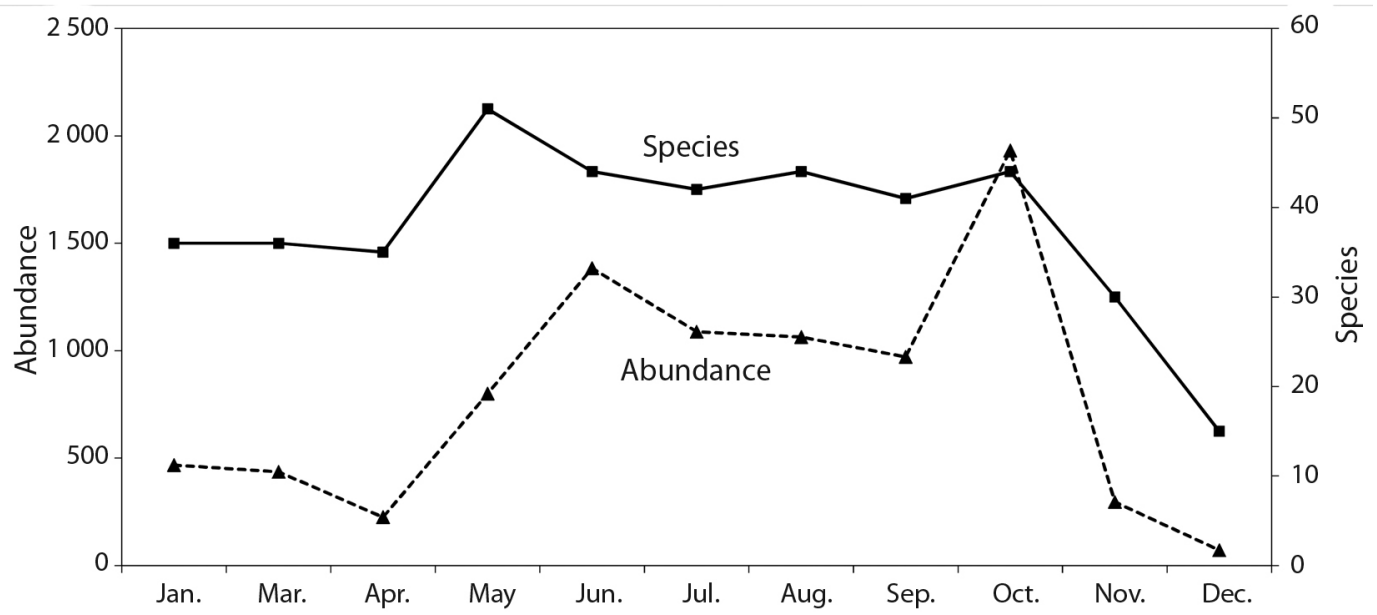

Fig. 2. Phenology of Papilionidae and Pieridae of the Loxicha Region, Oaxaca. Combined data of seven years of sampling. February was not sampled during this study.

during the rainy season (May to October), a common pattern in insects at these latitudes. Diversity reaches its maximum value at the beginning of the rainy season (May), but abundance has its maximum just before the end of this season (October). After October, both parameters suddenly decrease, being December the month with fewer species and abundance.

Elevational diversity patterns: Species richness and diversity $\left(\mathrm{e}^{H}\right)$ of Papilionidae decrease abruptly at higher altitudes (Fig. 3A). Papilionidae species richness is higher below the $750 \mathrm{~m}, 81 \%$ of the species are present in the low-level. No species of this family where recorded above $2700 \mathrm{~m}$ On the other hand, Pieridae has more observed species in the 0-750 $\mathrm{m}$ range (Fig. 3B); however, estimated species richness is similar among the three levels, just a little higher for the mid-level (750-1 $800 \mathrm{~m}$; 38 species, $78 \%$ ) and lower for the high-level (29 species, $71 \%$ ). Even if species richness of Pieridae is similar along the altitudinal range, diversity is much higher in the low-level (Fig. 3B). This means that species evenness is higher at the 0-750 level, 

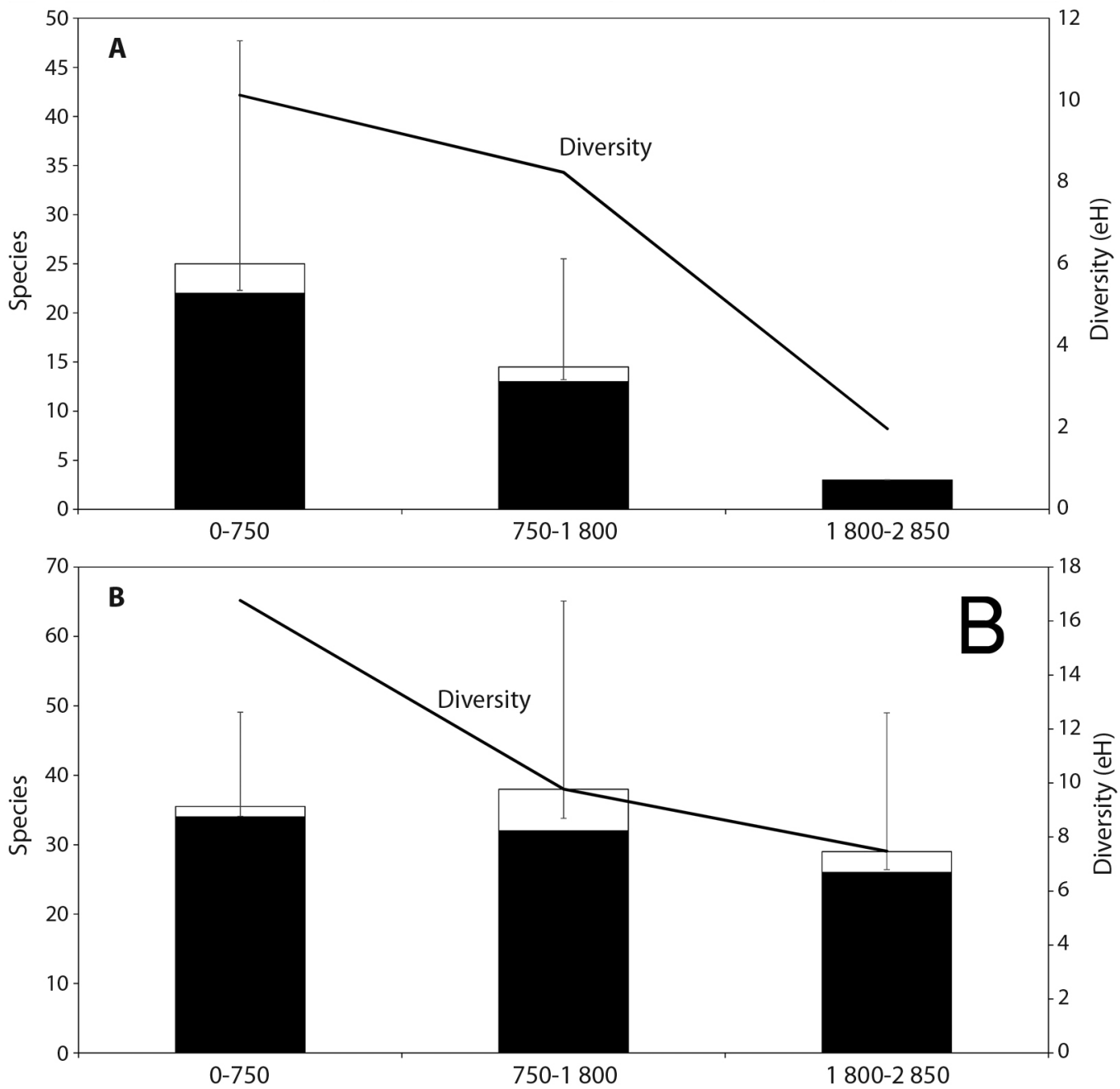

Fig. 3. Observed (black) and estimated (white) species richness and diversity (exponential of Shannon-Wiener index) in three altitudinal levels of the Loxicha Region. A. Papilionidae; B. Pieridae.

without dominant species. Still, there are some rare species of both families at this altitude, like Baronia b. brevicornis, Battus eracon, B. p. philenor, Abaeis nicippe, Catasticta n. nimbice, and Enantia mazai diazi. On the other hand, dominance increases at higher levels where some species are clearly more abundant than others, mainly of the genus Eurema.

Altitudinal abundance patterns: Like diversity, abundance is also higher at the lowlevel (79 \%, 646 records of Papilionidae; 52 $\%, 4111$ records of Pieridae), decreasing as altitude increases. However, at the high-level, abundance patterns are different for each family. Papilionidae abundances at the middle and high levels were almost the same, 82 records $(10 \%)$ at $750-1800 \mathrm{~m}$ and 91 records $(11 \%)$ at $1800-2850 \mathrm{~m}$. In contrast to Pieridae abundance, with $34 \%$ of the records (2702) at the mid-level, and just $14 \%$ (1101 records) at the high-level.

Each level has dominant or characteristic species of Papilionidae. In the low-level Protographium epidaus fenochionis with 206 specimens accounts for $32 \%$ of the records; 
in the mid-level Pterourus baroni is the most abundant with 30 records (37\%); dominance is higher in the high-level, $78 \%$ of the specimens (71) belong to Pterourus m. multicaudata. The genus Eurema is the most abundant Pieridae in all altitudinal levels. Eurema daira with 764 specimens $(19 \%)$ is dominant in the low-level; in the mid-level, E. salome jamapa comprises $37 \%$ of the abundance, this species is also abundant in the high-level with $31 \%$ of the records (343), exceeded only by Eurema m. mexicana that has $33 \%$ of the specimens (360). In the higher levels, these two species combined account for $64 \%$ of the abundance.

Altitudinal distribution patterns of species are different in both families. Parides photinus is the only Papilionidae present in all altitudinal levels; 15 species are present in just one level, 13 of which are exclusive of the low-level. On the contrary, 18 species of Pieridae are distributed along the whole altitudinal range, but with exclusive species in each level. Dismorphia amphione isolda, Itaballia demophile centralis, Melete lycimnia isandra and Prestonia clarki are only found in the low-level; Lieinix nemesis nayaritensis and Pereute charops sphocra are exclusive of the mid-level; lastly, Catasticta oaxaca, Eucheira s. socialis, and Hesperocharis graphites avivolans are present only in the highest altitudes.

Diversity patterns by vegetation type: The altitudinal range with most species is from sea level to $750 \mathrm{~m}$, where the TDF (42 species) and TSDF (52 species) are present, nine species are exclusive to these vegetation types. The high richness of species in these vegetational types, compared with the other types, is due to the diversity patterns of Papilionidae, with 22 species combined in the TDF and TSDF, 85 $\%$ of the species of this family in the Loxicha Region (Fig. 4A). Species richness of Pieridae is similar among vegetation types, with just a difference of six species among the four lowelevation types; richness clearly decreases in the OPF (Fig. 4B).

Diversity patterns by vegetation type are distinct for each family. In Papilionidae (Fig.
$4 \mathrm{~A})$, the TDF is the richest vegetation type with 23 estimated species, but 15 observed species. The highest observed richness of Papilionidae is for the TSDF with 20 species, but only 21 estimated species. These two vegetation types and the CF have similar species richness, but distinct species composition. The difference in the observed and estimated species richness in the TDF is due to the presence of rare species since six of the 15 species have only one record. High rareness increases the estimation value and the CI (Fig. 4A). Sites with OPCF have lowest species richness of Papilionidae with three species recorded, a great difference compared with the other types, except OPF, where no species were collected.

Species richness of Pieridae in all vegetation types is higher than Papilionidae, and nonsignificantly different among types according to the CI (Fig. 4B); except for the OPF than have significantly fewer species than the other types. Pieridae in the TSDF and CF, the vegetation types with more species recorded, have the same observed (32) and estimates (33) species richness. Rareness is lower for Pieridae than Papilionidae, resulting in lower estimations and narrower CI (Fig. 4). Estimations show that all vegetation types have enough sampling effort, except for Papilionidae in the TDF where more sampling effort is needed.

Abundance patterns by vegetation type: The TSDF have the highest abundance for both families, $40 \%$ of the specimens of Papilionidae and $39 \%$ of the specimens of Pieridae. The abundance of Papilionidae in the TDF is slightly lower (39\%), while for Pieridae the second type with most records is the CF $(35 \%)$. The difference of the abundance of each family in the TDF relative to other types is noteworthy, for Papilionidae this vegetation type has just 14 fewer records than the TSDF, but for Pieridae, the TDF is in fourth place with just $13 \%$ of the abundance and 13 fewer specimens than the OPCF that is in third place. The OPF has the lowest abundance of both families.

Some vegetation types have dominant species. For Papilionidae dominance is clear in the 

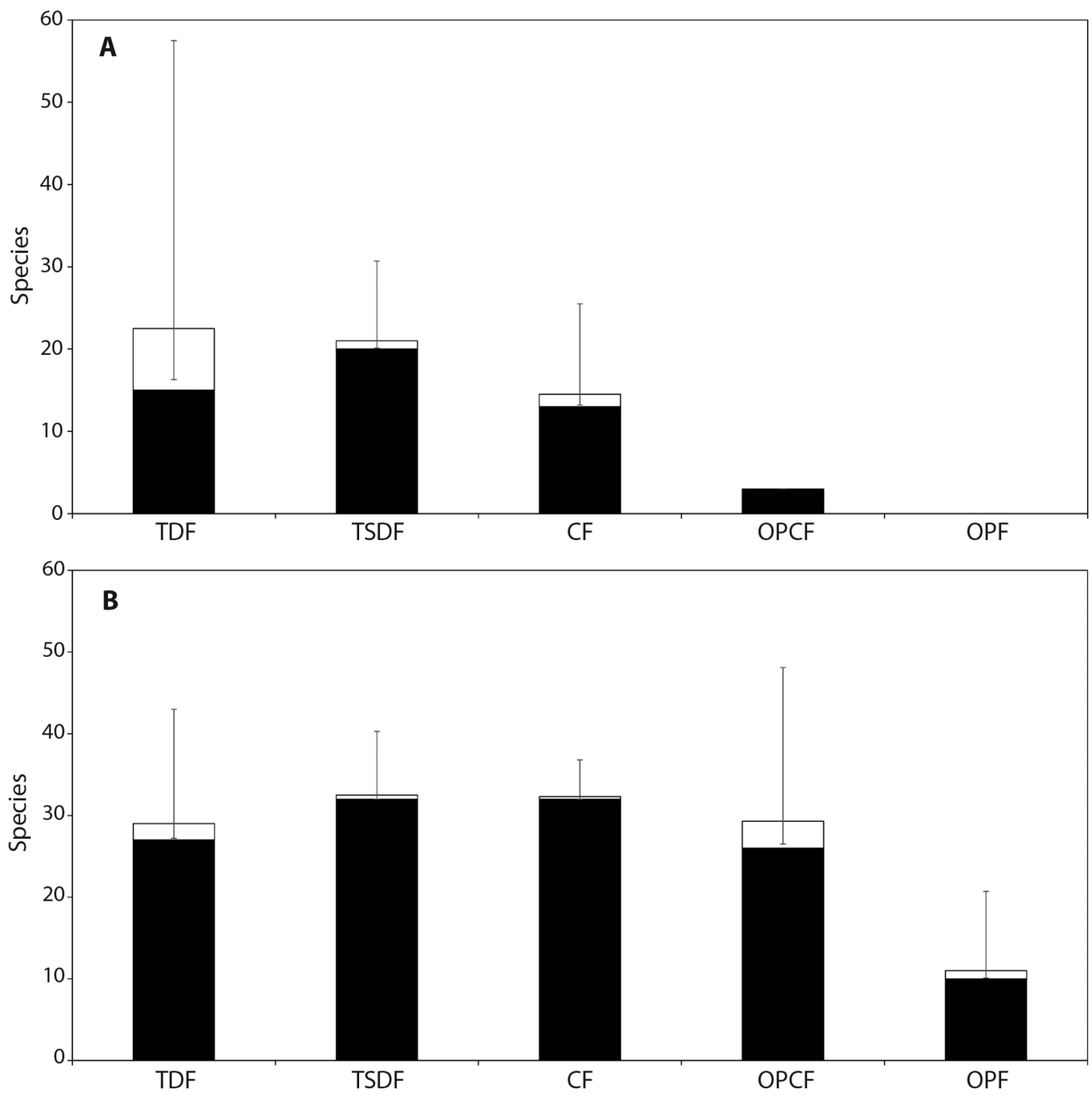

Fig. 4. Observed (black) and estimated (white) species richness by vegetation types of the Loxicha Region. A. Papilionidae; B. Pieridae.

OPCF where Pterourus m. multicaudata comprise $78 \%$ of the records (71). In the TDF, 59\% of the specimens (185) are of Protographium epidaus fenochionis. Dominance is lower in the $\mathrm{CF}$, where Pterourus baroni represents $37 \%$ of the abundance with 30 specimens. In the TSDF the most abundant Papilionidae species is Protesilaus macrosilaus penthesilaus, with 72 specimens, only $22 \%$ of the records.

The dominance of Pieridae in the OPF is shared by two species Eurema salome jamapa
(20 specimens) and Hesperocharis graphites avivolans (17 specimens) that together contain $64 \%$ of the records. The OPCF shows a similar pattern with Eurema m. mexicana (355) and E. salome jamapa (323) comprising $65 \%$ of the abundance. The genus Eurema is also dominant in the CF where E. salome jamapa has $37 \%$ of the records (997), and in the TSDF with $E$. daira (669) and E. albula celata (403) representing 22 and $13 \%$ of the records. Relative abundance among species is more even in the 
TABLE 4

Exclusive species of each vegetation type

\begin{tabular}{|c|c|c|c|c|}
\hline & TDF & TSDF & $\mathrm{CF}$ & $\mathrm{OPCF}$ \\
\hline \multicolumn{5}{|l|}{ Papilionidae } \\
\hline Baronia brevicornis brevicornis & 8 & & & \\
\hline Battus eracon & 1 & & & \\
\hline Battus philenor philenor & & 1 & & \\
\hline Heraclides androgeus reyesorum & & 6 & & \\
\hline Heraclides erostratus vazquezae & & & 4 & \\
\hline Papilio polyxenes asterius & & 3 & & \\
\hline Protesilaus macrosilaus penthesilaus & & 72 & & \\
\hline Protographium agesilaus fortis & & 34 & & \\
\hline Pterourus multicaudata multicaudata & & & & 71 \\
\hline Pterourus pilumnus & & & 2 & \\
\hline \multicolumn{5}{|l|}{ Pieridae } \\
\hline Catasticta oaxaca & & & & 19 \\
\hline Eucheira socialis socialis & & & & 1 \\
\hline Ganyra phaloe tiburtia* & $*$ & & & \\
\hline Lieinix nemesis nayaritensis & & & 9 & \\
\hline Melete lycimnia isandra & & 59 & & \\
\hline Pereute charops sphocra & & & 21 & \\
\hline Prestonia clarki & 13 & & & \\
\hline
\end{tabular}

* = not collected, bibliographic record.

Vegetation types, $\mathrm{TDF}=$ tropical deciduous forest, $\mathrm{TSDF}=$ tropical sub-deciduous forest, $\mathrm{CF}=$ cloud forest (low and middle levels), $\mathrm{OPCF}=$ oak-pine and cloud forest (high level), $\mathrm{OPF}=$ oak-pine forest.

OPF has no exclusive species of Papilionidae nor Pieridae.

TDF, being Pyrisitia proterpia the most abundant species (161 specimens) with just 16\% of the records.

Most of the species were collected in two or more vegetation types. However, 10 species of Papilionidae and six of Pieridae are exclusive of a single type (Table 4). Regarding Papilionidae, Parides photinus is the only species recorded in all vegetations types, while seven species of Pieridae are present in all vegetation types: Eurema daira, Eurema $m$. mexicana, Eurema salome jamapa, Ganyra josephina josepha, Nathalis iole iole, and Zerene c. cesonia.

\section{DISCUSSION}

Biogeographic history of the Sierra Madre del Sur has produced isolation and creation of endemic butterflies v. gr. Papilionidae:
Heraclides androgeus reyesorum, Pyrrhosticta baroni; Pieridae: Dismorphia amphiona isolda and; Riodinidae: Lamphiotes velazquezi, Theope villai, Mesene jimena, and Synargis nymphidioides praedictum (Arellano-Covarrubias, Llorente-Bousquets, \& Luis-Martínez, 2018). High altitude and CF endemics of the Loxicha Region have affinities with the Centroamerican Mountain Nucleus (sensu Halffter, 1976); while tropical forest endemic species are more related with the tropical communities of the Atlantic slope and Southeast of Mexico. These communities are, in general, similar to those in the Pacific Coast, although the North of Michoacán has distinct subspecies.

Species list has a high level of completeness according to the estimators (Table 3). However, there must be some rare species yet to be recorded (Colwell \& Coddington, 1994; Halffter \& Moreno, 2005). Species richness 
estimation allows the evaluation of completeness of the list and the comparison with other lists (Soberón \& Llorente, 1993; Moreno, 2001). It also generates reliable data for niche modeling providing presence data, but also absence data. If the species list of an area is more or less complete, then the absence of non-listed species can be assumed with a high level of certainty. These 'real' absences can be included in the niche models increasing the model support (Hirzel, Hausser, Chessel, \& Perrin, 2002; Václavík \& Meentemeyer, 2009).

Llorente-Bousquets (1984) divides the Lepidoptera fauna of the cloud forests of Mexico in three altitudinal levels: first, the low level (600-1400 m) has characteristic species associated with the neotropics; the mid-level (1200-1800 m) with fauna that diversified in the Central American Nucleus (sensu Halffter, 1976); second, the high level (1800-2600 m) described by Llorente-Bousquets and LuisMartínez (1988). In the Loxicha Region, the $\mathrm{CF}$ of the middle and high levels can be found along the cliffs surrounded by OPF. This is common also in other sites of the Pacific slope like Sierra de Atoyac de Álvarez, Guerrero and Sierra de Manantlán, Jalisco-Colima. In the Atlantic slope, Sierra de Juárez has the three CF levels, with the low-level in an ecotone with the Tropical Evergreen Forest. Generally, each level of each of these regions has its own endemic species, except for Sierra de Atoyac which species are shared with other sites of the Pacific slope in Sierra Madre del Sur.

Distribution patterns are clearly different for each family. Papilionidae are restricted mainly to low altitudes $(80-750 \mathrm{~m})$, with $81 \%$ of the species in this range. This pattern is also seen in Riodinidae with 52 species, $84 \%$ of the richness, in low altitudes (ArellanoCovarrubias et al., 2018). The diversity of these two families, Papilionidae and Riodinidae, decreases suddenly above $1500 \mathrm{~m}$. Pieridae, on the contrary, do not show an evident decrease in diversity between 500 and $1800 \mathrm{~m}$ (Fig. $3 \mathrm{~A}$ ), with just three more species in the low altitudes. This pattern in Pieridae could be due to the wide ecological valence and dispersal capacity of the species of this family, except Dismorphiinae. Frequently, they make altitudinal migrations following cliffs, rivers, and streams. Six Pieridae species are distributed from sea level to $3000 \mathrm{~m}$ and 15 species from zero to $2500 \mathrm{~m}$, combined these 21 species comprise $50 \%$ of all Pieridae in the Loxicha Region. Contrary to Pieridae, Parides photinus is the only Papilionidae species recorded from 0 to $2500 \mathrm{~m}$, seven species are distributed from sea level to $1800 \mathrm{~m}$. These patterns agree with those found in other altitudinal ranges sampled in the last 30 years, in the Atlantic and Pacific slopes (Luis-Martínez et al., 1991; Vargas-Fernández et al., 1991, 1999). Phenology also agrees with the common pattern found for Lepidoptera in other faunistic studies in tropical regions of Mexico (Luis-Martínez et al., 1991; Vargas-Fernández et al., 1991, 1999; Monteagudo-Sabaté et al., 2001); with adults flying in the rainy season from May through October, and most species undergoing diapause in the winter.

In summary, the list of species of the Loxicha Region is increased with five new records of Papilionidae and seven of Pieridae. This total is 69 species; 27 Papilionidae, and 42 Pieridae. New records are from vegetation types and altitudinal ranges previously undersampled and considered with low species richness and abundance. These records place the Loxicha Region as the most diverse within the Pacific slope and the second of the state of Oaxaca. The list of species has, at least, a level above $87 \%$ of completeness according to the estimators. This means that sampling was sufficient, with the exception of the Papilionidae of the TDF and above $2500 \mathrm{~m}$ for both families, where more sampling is needed to complete the lists. This completeness level allows the comparison of the list for faunistic, ecological or biogeographic research.

Ethical statement: authors declare that they all agree with this publication and made significant contributions; that there is no conflict of interest of any kind; and that we followed all pertinent ethical and legal procedures 
and requirements. All financial sources are fully and clearly stated in the acknowledgements section. A signed document has been filed in the journal archives.

\section{ACKNOWLEDGMENTS}

JLB and ALM thank the projects DGAPA PAPIIT IN212418, PAPIME PE202820, CONACyT 284966, and CONABIO JF018 for financial support. MTO thanks the Postdoctoral Research Fellowship CONACyT 284966. AAC thanks the Posgrado en Ciencias Biológicas de la Universidad Nacional Autónoma de México. We thank the Evolutionary Biology Department of the Facultad de Ciencias, UNAM, Armando Canavati, owner of the Hagia Sofía Ranch, and the authorities of the Parque Nacional Huatulco for the support during this project. To Sandra Nieves, Blanca Claudia Hernández and other colleagues and students who participated in the field work and Adriana Atzinameyali Sánchez Castañeda who processed the recollected material. The authors thank the reviewers for their comments on the manuscript.

\section{RESUMEN}

Distribución y diversidad de Papilionidae y Pieridae (Lepidoptera: Papilionoidea) en la región Loxicha, Oaxaca, México. Introducción: Una lista de especies confiable y el análisis de los patrones de diversidad de taxones hiperdiversos, como las mariposas, son fundamentales para el monitoreo y manejo de recursos biológicos. Oaxaca es uno de los estados más diversos de México y mucha de su diversidad aun es desconocida. Objetivo: Estimar y describir la riqueza de especies y diversidad de Papilionidae y Pieridae en un gradiente altitudinal y cinco tipos de vegetación presentes en la Región Loxicha, Oaxaca, en la Sierra Madre del Sur. Métodos: El esfuerzo de muestreo comprendió 222 días a lo largo de siete años. Se estima la diversidad alfa para 17 sitios dentro de un gradiente altitudinal de 880 a $2850 \mathrm{~m}$ con cinco tipos de vegetación: bosque tropical caducifolio, bosque tropical subcaducifolio, bosque mesófilo (nivel bajo y medio), bosque de pino-encino con bosque mesófilo (nivel alto) y bosque de pino-encino. Resultados: Se obtuvo una lista de 69 especies (27 Papilionidae y 42 Pieridae), de 34 géneros y cinco subfamilias, a partir de los registros en la literatura y el trabajo de campo. Estas especies representan el $60 \%$ de los Pieridae y el $48 \%$ de los Papilionidae registrados para el estado. A nivel nacional, la región Loxicha tiene el $36 \%$ de las Pieridae y el $30 \%$ de las Papilionidae del país. Las familias presentan patrones diferentes de riqueza de especies por tipo de vegetación. Papilionidae es más rica en el bosque tropical caducifolio con 23 especies estimadas y la mayoría de las especies de esta familia ( $84 \%$ ) están por debajo de los $500 \mathrm{~m}$ Mientras que la riqueza de especies de Pieridae no presenta diferencias significativas entre los tipos de vegetación, excepto por el bosque de pino-encino que tiene menos especies que los demás tipos. El gradiente altitudinal se dividió en tres pisos (0-750, 750-1 800, 1 $800-2850 \mathrm{~m}$ ) con una reducción de la riqueza de especies y diversidad de ambas familias en altitudes mayores. Conclusiones: Las especies de Papilionidae están más restringidas a un tipo de vegetación o piso altitudinal que las especies de Pieridae. Probablemente por la gran vagilidad, valencia ecológica más amplia y capacidad de migraciones altitudinales de la mayoría de las Pieridae.

Palabras clave: mariposas, abundancia, estimación de la riqueza de especies, distribución altitudinal, bosque mesófilo.

\section{REFERENCES}

Álvarez-García, H., Ibarra, A. V., \& Escalante, P. (2016). Riqueza y distribución altitudinal de las mariposas de la Sierra Mazateca, Oaxaca (Lepidoptera: Papilionoidea). Acta Zoológica Mexicana (Nueva Serie), 32(3), 323-347. DOI: 10.21829/azm.2016.323967

Arellano-Covarrubias, A., Llorente-Bousquets, J., \& LuisMartínez, A. (2018). Distribución y fenología de la familia Riodinidae (Lepidoptera: Papilionoidea) en el bosque tropical subcaducifolio de Oaxaca, México. Revista de Biología Tropical, 66(2), 503-558. DOI: 10.15517/RBT.V66I2.33378

Arita, H., \& Rodríguez, P. (2001). Ecología Geográfica y Macroecología. In J. Llorente Bousquets, \& J. J. Morrone (Eds.), Introducción a la biogeografia en Latinoamérica: teorías, conceptos, métodos \& aplicaciones (pp. 63-80). Ciudad de México, México: Facultad de Ciencias, UNAM.

Beccaloni, G. W., \& Gaston, K. J. (1995). Predicting the species richness of neotropical forest butterflies: Ithomiinae (Lepidoptera: Nymphalidae) as indicators. Biological Conservation, 71(1), 77-86. DOI: 10.1016/0006-3207(94)00023-J

Bonebrake, T. C., Ponisio, L. C., Boggs, C. L., \& Ehrlich, P. R. (2010). More than just indicators: A review of tropical butterfly ecology and conservation. Biological Conservation, 143(8), 1831-1841. DOI: 10.1016/j.biocon.2010.04.044

Chao, A., \& Shen, T. J. (2003). Nonparametric estimation of Shannon's index of diversity when there are unseen species in sample. Environmental 
and Ecological Statistics, 10(4), 429-443. DOI: 10.1023/A:1026096204727

Chao, A., \& Shen, T. J. (2010). Program SPADE (Species Prediction and Diversity Estimation). User guide. Retrieved from http://chao.stat.nthu.edu.tw

Chao, A., Chazdon, R. L., Collwel, R. K., \& Shen, T. J. (2005). Un nuevo método estadístico para la evaluación de la similitud en la composición de especies con datos de incidencia y abundancia. In G. Halffter, J. Soberón, P. Koleff, \& A. Melic (Eds.), Sobre diversidad biológica: el significado de las diversidades Alfa, Beta y Gama (Vol. 4, pp. 85-96). Zaragoza, España: $\mathrm{m} 3 \mathrm{~m}$-Monografías 3ercer milenio.

Chazdon, R. L., Colwell, R. K., Denslow, J. S., \& Guariguata, M. R. (1998). Statistical methods for estimating species richness of woody regeneration in primary and secondary rain forests of Northeastern Costa Rica. In F. Dallmeier \& J. A. Comiskey (Eds.), Forest biodiversity research, monitoring and modeling: Conceptual background and Old World case studies (pp. 285-309). Paris, France: Parthenon Publishing.

Colwell, R. K. (2016). EstimateS: Statistical estimation of species richness and shared species from samples (Version 9). Retrieved from https://purl.oclc.org/ estimates

Colwell, R. K., \& Coddington, J. A. (1994). Estimating terrestrial biodiversity through extrapolation. Philosophical Transactions of the Royal Society of London. Series B: Biological Sciences, 345(1311), 101-118.

García-Mendoza, A. J., Ordóñez, M. J., \& Briones-Salas, M. (Eds). (2004) Biodiversidad de Oaxaca. Ciudad de México, México: Instituto de Biología, Universidad Nacional Autónoma de México.

González-Valdivia, N., Ochoa-Gaona, S., Pozo, C., Ferguson, B. G., Rangel-Ruiz, L. J., Arriaga-Weiss, S. L., ... Kampichler, C. (2011). Indicadores ecológicos de hábitat y biodiversidad en un paisaje neotropical: perspectiva multitaxonómica. Revista de Biología Tropical, 59(3), 1433-1451.

Halffter, G. (1976). Distribución de los insectos en la Zona de Transición Mexicana. Relaciones con la entomofauna de Norteamérica. Folia Entomológica Mexicana, 35, 1-64.

Halffter, G., \& Moreno, C. E. (2005). Significado biológico de las diversidades alfa, beta y gamma. In G. Halffter, J. Soberón, P. Koleff, \& A. Melic (Eds.), Sobre Diversidad Biológica: el significado de las Diversidades Alfa, Beta y Gamma (Vol. 4, pp. 5-18). Zaragoza, España: m3m-Monografías 3ercer Milenio.

Hirzel, A. H., Hausser, J., Chessel, D., \& Perrin, N. (2002). Ecological-niche factor analysis: how to compute habitat-suitability maps without absence data? Ecology, 83(7), 2027-2036. DOI:
10.1890/0012-9658(2002)083[2027:ENFAHT]2.0. $\mathrm{CO} ; 2$

Holt, R. (1993). Ecology at the mesoscale: The influence of regional processes on local communities. In R. Ricklefs \& Schluter, E. (Eds.), Species Diversity in ecological communities: Historical and Geographical Perspectives (pp. 77-88). Chicago, USA: University Chicago Presses.

Jost, L. (2006). Entropy and diversity. Oikos, 113(2), 363375. DOI: $10.1111 / \mathrm{j} .2006 .0030-1299.14714 . \mathrm{x}$

Kocher, S. D., \& Williams, E. H. (2000). The diversity and abundance of North American butterflies vary with habitat disturbance and geography. Journal of Biogeography, 27(4), 785-794. DOI: 10.1046/j.1365-2699.2000.00454.x

Kristensen, N. P. (1976). Remarks on the family-level phylogeny of butterflies (Insecta, Lepidoptera, Rhopalocera). Zeitschrift für Zoologische Systematik und Evolutions Forschung, 14(1), 25-33.

Llorente-Bousquets, J. (1984). Sinopsis sistemática y biogeográfica de los Dismorphiinae de México con especial referencia al género Enantia Huebner (Lepidoptera: Pieridae). Folia Entomológica Mexicana, 58, 1-207.

Llorente Bousquets, J., \& Luis-Martinez, A. (1988). Nuevos Dismorphiini de México y Guatemala (Lepidoptera: Pieridae). Folia Entomológica Mexicana, 74, 159-178.

Llorente-Bousquets, J., Luis-Martínez, A., \& VargasFernández, I. (2006). Apéndice general de Papilionoidea: Lista sistemática, distribución estatal y provincias biogeográficas. In J. J. Morrone \& J. Llorente-Bousquets (Eds.), Componentes bióticos principales de la entomofauna mexicana (Vol. II, pp. 945-1009). Ciudad de México, México: Las Prensas de Ciencias, UNAM.

Llorente-Bousquets, J. E., Oñate-Ocaña, L., Luis-Martínez, A., \& Vargas-Fernández, I. (1997). Papilionidae y Pieridae de México: distribución geográfica e ilustración. Ciudad de México, México: Las Prensas de Ciencias, UNAM.

Llorente-Bousquets, J., Trujano-Ortega, M., Luis-Martínez, A., Castro, J., \& Vargas-Fernández, I. (2006). Patrones de distribución de la familia Pieridae (Lepidoptera). In J. J. Morrone \& J. Llorente-Bousquets (Eds.), Componentes bióticos principales de la entomofauna mexicana (Vol. 2, pp. 715-770). Ciudad de México, México: Las Prensas de Ciencias, UNAM.

Llorente-Bousquets, J., Vargas-Fernández, I., Luis-Martínez, A., Trujano-Ortega, M., Hernández-Mejía, B. C., \& Warren, A. D. (2014). Biodiversidad de Lepidoptera en México. Revista Mexicana de Biodiversidad, Suplemento Biodiversidad de México, 85, S353-S371. DOI: 10.7550/rmb.31830 
Luis-Martínez, A., Llorente-Bousquets, J., \& VargasFernández, I. (2005). Una megabase de datos de mariposas y la regionalización biogeográfica de México. In J. Llorente-Bousquets \& J. J. Morrone, (Eds.), Regionalización geográfica en Iberoamérica y tópicos afines: Primeras Jornadas Biogeográficas de la Red Iberoamericana de Biogeografia y Entomología Sistemática (RIBES XII.X-CYTED) (pp. 269-294). Ciudad de México, México: Las Prensas de Ciencias, UNAM.

Luis-Martínez, A., Vargas-Fernández, I., \& Llorente-Bousquets, J. (1991). Lepidopterofauna de Oaxaca I: Distribución y fenología de los Papilionoidea de la Sierra de Juárez. Publicaciones especiales del Museo de Zoología, 3, 1-119.

Luis-Martínez, A., Hernández-Mejía, B., Trujano-Ortega, M., Warren, A., Salinas-Gutiérrez, J., Ávalos-Hernández, O., ... Llorente-Bousquets, J. (2016). Avances faunísticos en los Papilionoidea (Lepidoptera) sensu lato de Oaxaca, México. Southwestern Entomologist, 41(1), 171-224.

Magurran, E. A. (2006). Biological diversity. Current Biology, 15(4), 116-118.

Martín-Piera, F. (2000). Estimaciones prácticas de biodiversidad utilizando taxones de alto rango en insectos. In F. Martín-Piera, J. J. Morrone, \& A. Melic (Eds.), Hacia un proyecto CYTED para el inventario y estimación de la diversidad entomológica en Iberoamérica: PrIBES 2000 (Vol. 1, pp. 35-54). Zaragoza, España: m3m-Monografías 3ercer Milenio.

Maza, J., \& Díaz, A. (1978). Dos nuevas especies del género Anaea Hübner de México (Nymphalidae, Charaxinae). Revista de la Sociedad Mexicana de Lepidopterología, 4(1), 29-38.

Maza, R. G., \& Maza, J. (1983). Descripción de nuevas subespecies del género Callicore Hübner de México y Guatemala (Nymphalidae: Nymphalinae). Revista de la Sociedad Mexicana de Lepidopterología, 8(1), 3-11.

Miller, L. D. (1972). Revision of the Euptychiini (Satyridae). 1. Introduction and Paramacera Butler. Bulletin of the Allyn Museum, 8, 1-18.

Miller, L. D. (1974). Revision of the Euptychiini (Satyridae). 2. Cyllopsis R. Felder. Bulletin of the Allyn Museum, 20, 1-98.

Miller, J. Y., \& Miller, L. D. (1979). Notes on Mexican Actinote (Nymphalidae: Acraeinae) and their relatives, with description of a new subspecies. Journal of the Lepidopterists' Society, 32(4), 261-272.

Miller, L. D., \& Rotger, B. (1979). Two new Chlosyne (Nymphalidae) from Mexico. Bulletin of the Allyn Museum, 54, 1-4.
Monteagudo-Sabaté, D., \& Luis-Martínez, A. (2013). Patrones de riqueza altitudinal de Papilionidae, Pieridae y Nymphalidae (Lepidoptera: Rhopalocera) en áreas montañosas de México. Revista de Biología Tropical, 61(3), 1509-1520. DOI: 10.15517/RBT. V61I3.11980

Monteagudo-Sabaté, D., Luis-Martínez, A., Vargas-Fernández, I., \& Llorente-Bousquets, J. (2001). Patrones altitudinales de diversidad de mariposas en la Sierra Madre del Sur (México) (Lepidoptera: Papilionoidea). SHILAP Revista de Lepidopterología, 29(115), 207-237.

Moreno, C. E. (2001). Métodos para medir la biodiversidad (Vol. 1). Zaragoza, España: M\&T-Manuales y Tesis SEA.

Morrone, J. J. (2005). Hacía una síntesis biogeográfica de México. Revista Mexicana de Biodiversidad, 76(2), 207-252.

Morrone, J. J., Espinosa-Organista, D., \& Llorente-Bousquets, J. (2002). Mexican biogeographic provinces: preliminary scheme, general characterizations, and synonymie. Acta Zoológica Mexicana (Nueva Serie), 85, 83-108.

Oñate-Ocaña, L., Trujano-Ortega, M., Llorente-Bousquets, J., Luis-Martínez, A., \& Vargas-Fernández, I. (2006). Patrones de distribución de la familia Papilionidae (Lepidoptera). In J. J. Morrone \& J. Llorente-Bousquets (Eds.), Componentes bióticos principales de la entomofauna mexicana (Vol. II, pp. 661-714). Ciudad de México, México: Las Prensas de Ciencias, UNAM.

Pozo, C., Luis Martínez, A., Salas-Suárez, N., TrujanoOrtega, M., \& Llorente Bousquets, J. (2015). Mariposas diurnas: bioindicadoras de eventos actuales e históricos. In C. A. González Zuarth, A. Vallarino, J. C. Pérez-Jiménez, \& A. M. Low-Pfeng (Eds.), Bioindicadores: guardianes de nuestro futuro ambiental (pp. 327-348). México: ECOSUR-INECC.

Rodríguez, P., \& Arita, H. T. W. (2005). La diversidad beta como un elemento integrador de distintos patrones macroecológicos. In G. Halffter, J. Soberón, P. Koleff, \& A. Melic (Eds.), Sobre Diversidad Biológica: el significado de las Diversidades alfa, beta y gamma (Vol. 4, pp. 41-52). Zaragoza, España: m3m-Monografías 3ercer Milenio.

Rzedowski, J. (2006). Vegetación de México. 1ra. Edición digital. México: Comisión Nacional para el Conocimiento y Uso de la Biodiversidad. México: Editorial Limusa, S. A.

Soberón, J. M., \& Llorente-Bousquets, J. (1993). The use of species accumulation functions for the prediction of species richness. Conservation Biology, 7(3), 480488. DOI: $10.1046 / \mathrm{j} .1523-1739.1993 .07030480 . x$

Sparrow, H. R., Sisk, T. D., Ehrlich, P. R., \& Murphy, D. D. (1994). Techniques and guidelines for monitoring 
neotropical butterflies. Conservation Biology, 8(3), 800-809.DOI: 10.1046/j.1523-1739.1994.08030800.x

Thomas, J. A. (2005). Monitoring change in the abundance and distribution of insects using butterflies and other indicator groups. Philosophical Transactions of the Royal Society B: Biological Sciences, 360(1454), 339-357. DOI: $10.1098 /$ rstb.2004.1585

Václavík, T., \& Meentemeyer, R. K. (2009). Invasive species distribution modeling (iSDM): Are absence data and dispersal constraints needed to predict actual distributions? Ecological Modelling, 220(23), 32483258. DOI: 10.1016/j.ecolmodel.2009.08.013

Vargas-Fernández, I., Llorente-Bousquets, J., \& LuisMartínez, A. (1991). Lepidopterofauna de Guerrero
I: distribución y fenología de los Papilionoidea de la Sierra de Atoyac. Publicaciones especiales del Museo de Zoología, 2, 1-127.

Vargas-Fernández, I., Llorente-Bousquets, J., \& LuisMartínez, A. (1999). Distribución de los Papilionoidea (Lepidoptera: Rhopalocera) de la Sierra de Manantlán (250-1,650 m) en los estados de Jalisco y Colima. Publicaciones especiales del Museo de Zoología, 11, 1-153.

Vargas-Fernández, I., Llorente-Bousquets, J., \& Luis-Martínez, A. (2016). Adiciones a la serie Papilionoidea de México: distribución geográfica e ilustración. Ciudad de México, México: Facultad de Ciencias, Universidad Nacional Autónoma de México. 